\title{
The Analysis of the Amount of Pollutants in Wastewater after Mechanical Treatment in the Aspect of their Susceptibility to Biodegradation in the Treatment Plant in Nowy Targ
}

\author{
Elwira Nowobilska-Majewska', Piotr Bugajski ${ }^{1 *}$ \\ 1 University of Agriculture of Krakow, al. Mickiewicza 24/28, 30-059 Kraków, Poland \\ * Corresponding author's e-mail: p.bugajski@urk.edu.pl
}

\begin{abstract}
The aim of this study was to determine the biodegradability of organic and biogenic contaminants in wastewater flowing into biological reactors in the treatment plant in Nowy Targ. The research period covered the years 2016 and 2017, when 87 samples of raw wastewater and 87 samples of wastewater after mechanical treatment were collected and subjected to physico-chemical analysis. In both types of wastewater, the size of the following indicators was analyzed: $\mathrm{BOD}_{5}, \mathrm{COD}$, total kjeldahl nitrogen $(\mathrm{TN})$ and total phosphorus (TP). The study verified the amount of pollutants in the raw wastewater in order to determine whether they are household wastewater. In the next stage of the analysis, the characteristic values of the analyzed indicators in wastewater after the mechanical treatment process were determined in order to indicate mutual dependences of organic and biogenic indicators. Based on the analysis, it was found that wastewater after mechanical treatment (in the case of its susceptibility to biological decomposition processes of organic pollutants) has an unfavorable $\mathrm{COD} / \mathrm{BOD}_{5}$ ratio. With regard to the susceptibility of wastewater to nitrification, denitrification and dephosphatation processes, in the majority of cases, wastewater is susceptible to these processes. It is recommended to apply an additional source of organic carbon to wastewater prior to biological treatment in order to improve the biodegradation of the analyzed pollutants.
\end{abstract}

Keywords: wastewater, biodegradability, mechanical treatment, relation: $\mathrm{COD} / \mathrm{BOD}_{5} \mathrm{BOD}_{5} / \mathrm{TN}^{\mathrm{BOD}} 5 / \mathrm{TP}$

\section{INTRODUCTION}

Design and modernization of a sewage treatment plant is a complicated process requiring a lot of knowledge from the designer [Arnold et al. 2000, Barnard 2000, Stańko 2016]. Mistakes made by the designer at this stage will result in improper operation of the facility and they are often difficult to repair at a later stage of the sewage treatment plant's operation [Dymaczewski et al. 2011, Łomotowski and Szpindor 1999, Bergel et al. 2017]. Currently, the implementation of projects concerning the technological process of a sewage treatment plant is supported by various types of computer programs that support and facilitate the designer's work [Klaczyński 2016, Heidrich and Witkowski 2010]. However, even the most perfect computer program requires initial calibration, i.e. entering the adequate output data. The project of a biological reactor causes many problems in the design of individual sewage treatment plants, because its design should take into account both the amount of incoming wastewater, as well as quality of this wastewater expressed in indicators of organic and biogenic pollutants. Bearing in mind that in Poland (in recent years) there is a clear development of wastewater management, as well as there are more and more newly constructed wastewater treatment plants and old plants are modernized, the designers should take into account the current data for their design [Bugajski 2017, Pawełek 2016]. Large financial expenditures for this area of economy should be properly used and utilized. The topics discussed in this article should be the reasons for completing the knowledge for designers, but also for the operators of wastewater treatment plants on the amount of pollutants in wastewater before and after the mechanical treatment process. 
The main goal of the study was to determine the size of organic pollutants expressed in COD and $\mathrm{BOD}_{5}$ indicators, as well as biogenic compounds expressed as total nitrogen (as total kjeldahl nitrogen) and total phosphorus in wastewater after mechanical treatment in the treatment plant in Nowy Targ. The studies were carried out in terms of the evaluation of wastewater's susceptibility to biochemical degradation of organic and biogenic pollutants at the stage of biological treatment.

\section{MATERIALS AND METHODS}

The wastewater treatment plant in Nowy Targ was established in 1995 and is located at $49^{\circ} 29^{\prime} \mathrm{N}, 20^{\circ} 3^{\prime} \mathrm{E}$. Sewage from the municipal sewerage network is conveyed via a collector with a diameter $\mathrm{DN}=1.2 \mathrm{~m}$ to a pumping station. The main pumping station operates two pumps with a capacity of $1400 \mathrm{~m}^{3} \cdot \mathrm{h}^{-1}$. The pumps lift sewage to a height of $7.5 \mathrm{~m}$ for easy gravity flow through the entire process line. The sewage flows from the pumping station to a screen room, where screenings are caught on two step-screens with a slot width of $3 \mathrm{~mm}$ and a rated power of $1.5 \mathrm{~kW}$. Then, the wastewater flows into two sand traps, where mineral substances such as sand or gravel are sedimented. The sand separated by sedimentation is discharged into a sand scrubber separator, and after cleaning and dewatering, is fed into a container. The wastewater leaving the sand traps is conveyed by an $800 \mathrm{~mm}$ DN pipeline to two primary settling tanks. The horizontalflow settling tanks are $42.0 \mathrm{~m}$ long, $6.0 \mathrm{~m}$ wide and $3.6 \mathrm{~m}$ high. Primary sludge is collected in sludge hoppers and cyclically removed to a gravity thickener. Biological treatment is performed using the sequencing batch reactor method. In the biological treatment section, three bioreactors are installed, which work in 8-hour cycles. Each of them is $70 \mathrm{~m}$ long, $23 \mathrm{~m}$ wide and $4.5 \mathrm{~m}$ deep. Treated wastewater, after decanting, is discharged through a $1000 \mathrm{~mm} \mathrm{DN}$ collector pipe to the receiver, the Dunajec river [Bugajski i in. 2017b]. The location of Treatment Plant in Nowy Targ present on Figure.1

The study was conducted over two years (2016-2017). During this period 87 samples of raw wastewater and 87 samples wastewater after mechanical treatment were collected. The samples of influent wastewater were collected from the inlet channel using an autosampler programmed with respect to the wastewater flow rate. The wastewater samples after mechanical treatment were collected from the supply channel from settling tanks to biological reactors using autosampler too.

Samples of wastewater were subjected to physical-chemical analysis in accordance with the reference methods set out in the applicable legal acts (Dz.U./2014/1800).

- $\mathrm{BOD}_{5}$ - oxygen content was measured after 5 days of incubation at $20^{\circ} \mathrm{C}$ in OXI TOP - 197 WTW - BOD measurement according to EN 1899-1 and EN 1899-2 and for self-checks

- $\mathrm{COD}_{\text {cr }}$ - the dichromate test according to PNISO 6060:2006 - Water quality - Determination of chemical oxygen demand

- Total nitrogen (Kjeldahl) - according to PNEN 25663:2001 - Water quality - Determination of Kjeldahl nitrogen - Method after mineralization with selenium

- Total phosphorus - Hach DR 2800 spectrophotometer using LCK 349 and LCK 350 cuvette tests.

\section{RESULTS AND DISCUSSION}

The analysis of the results was carried out in three stages. In the first part, the characteristic values of the analyzed indicators in wastewater flowing into the plant and in wastewater after mechanical treatment were determined. In the second part of the analysis, correlations between the analyzed indicators in raw wastewater and wastewater after mechanical treatment were indicated. In the third part of the analysis, the susceptibility of wastewater after mechanical treatment to the biodegradability of organic and biogenic compounds was determined.

In the analyzed period, raw wastewater flowing into the indicated treatment plant was characterized by concentrations of organic and biogenic pollutants at the level corresponding to the domestic wastewater [Kaczor 2009, Heidrich and Kozak 2009, Bugajski and Bergel 2008].

The average $\mathrm{BOD}_{5}$ value was $498.5 \mathrm{mgO} \cdot \mathrm{dm}^{-3}$, while the median of this parameter was 487.6 $\mathrm{mgO}_{2} \cdot \mathrm{dm}^{-3}$. Fluctuations in the value of this parameter ranged from 206.5 to $935.0 \mathrm{mgO}_{2} \cdot \mathrm{dm}^{-3}$. The difference between the minimum and maximum $\mathrm{BOD}_{5}$ values was $728.5 \mathrm{mgO}_{2} \cdot \mathrm{dm}^{-3}$. The coefficient of variation for $\mathrm{BOD}_{5}$ in raw wastewater was $\mathrm{C}_{\mathrm{v}}=0.30$, which proves the average variation 


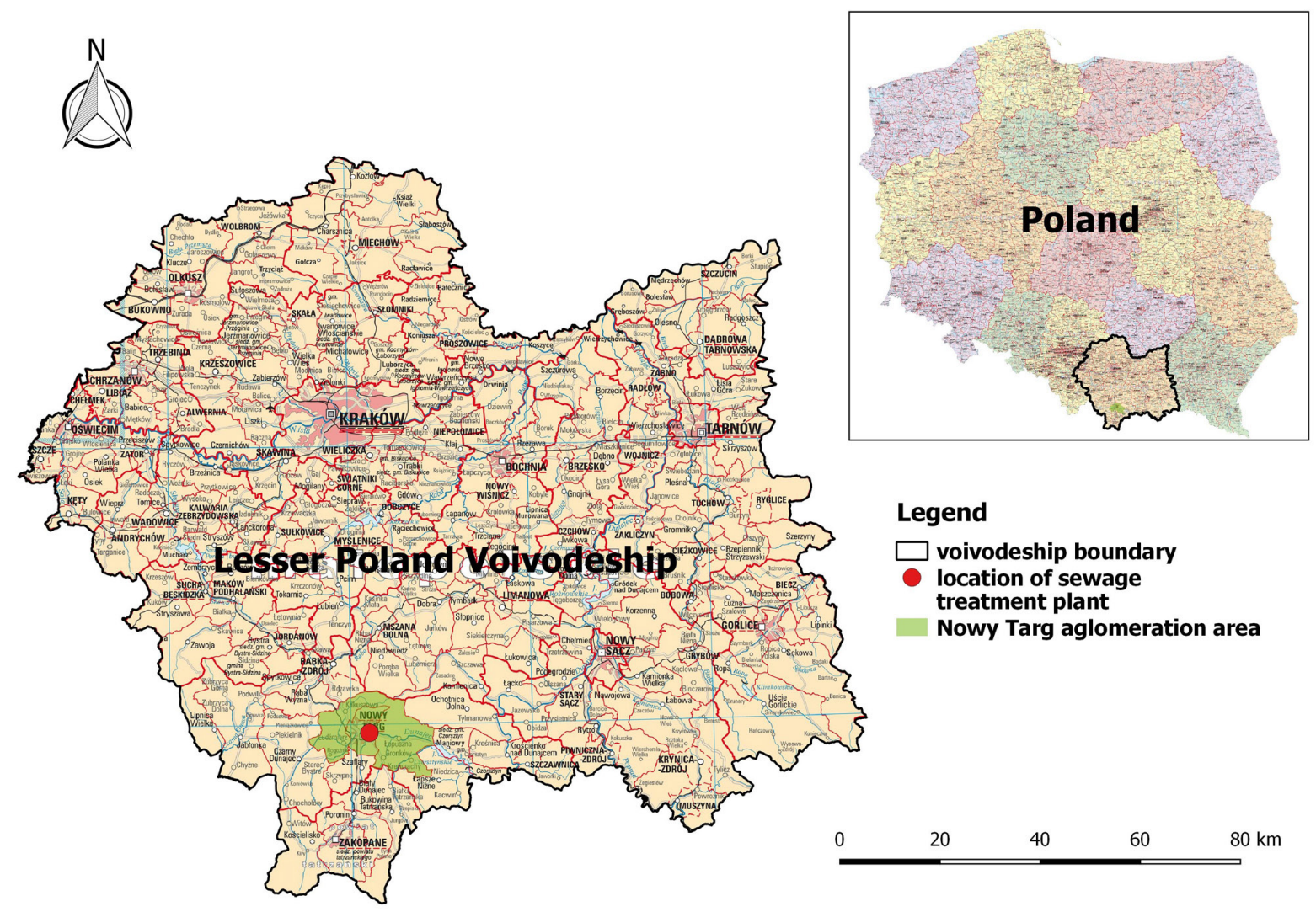

Figure 1. The location of the rural agglomeration of Nowy Targ against the background of the Masovian Voivodeship and Poland [source: own study]

according to the scale presented by Wawrzynek [2007]. In the case of another indicator from the organic group, i.e. COD, it was found that the average value of this parameter was 1615.9 $\mathrm{mgO}_{2} \cdot \mathrm{dm}^{-3}$, and the median $-1576.0 \mathrm{mgO} \cdot \mathrm{dm}^{-3}$. The minimal value of COD was $552.0 \mathrm{mgO}_{2} \cdot \mathrm{dm}^{-3}$, and the maximum value $-3074.0 \mathrm{mgO}_{2} \cdot \mathrm{dm}^{-3}$, so the difference between the minimum and the maximum was $2522 \mathrm{mgO}_{2} \cdot \mathrm{dm}^{-3}$. The coefficient of variation of COD in raw wastewater was $\mathrm{C}_{\mathrm{v}}=0.35$ and similarly to the case of the previous indicator, it was at the level of average differentiation. In reference to the third of the analyzed indicators (total nitrogen), it was found that the average concentration of this parameter in raw wastewater was $106.6 \mathrm{mgN}$ dian was $104.2 \mathrm{mgN}_{\mathrm{og}} \cdot \mathrm{dm}^{-3}$. The minimum concentration of total nitrogen in wastewater flowing into the plant was $44.3 \mathrm{mgN}_{\mathrm{og}} \cdot \mathrm{dm}^{-3}$, and the maximum $-209.3 \mathrm{mgN}_{\mathrm{og}} \cdot \mathrm{dm}^{-3}$. The coefficient of variation of total nitrogen concentrations in raw wastewater was $\mathrm{W}_{\mathrm{z}}=0.30$, which indicates the average variation of this parameter in wastewater flowing into the plant. The second of the analyzed biogenic indicators (total phosphorus) was characterized by the average value at the level of $18.2 \mathrm{mgP}_{\mathrm{og}} \cdot \mathrm{dm}^{-3}$, while the median was 17.2 $\mathrm{mgP} \mathrm{og} \cdot \mathrm{dm}^{-3}$. The minimum concentration of total phosphorus was $5.4 \mathrm{mgP}{ }_{\mathrm{og}} \cdot \mathrm{dm}^{-3}$, while the maximum concentration $-51.8 \mathrm{mgP} \mathrm{og}^{-3} \mathrm{dm}^{-3}$. The coefficient of variation for total phosphorus concentrations in raw wastewater was the highest of all analyzed parameters and amounted to $\mathrm{W}_{\mathrm{z}}=0.43$. This indicates a large variation of this parameter in wastewater flowing into the plant [Wawrzynek 2007]. Characteristic values and concentrations of the analyzed pollution indicators in raw wastewater are presented in Table 1.

In wastewater after mechanical treatment, $\mathrm{BOD}_{5}$ average value was lower by $24.2 \%$ than values in raw wastewater and amounted to $378.0 \mathrm{mgO}{ }_{2} \cdot \mathrm{dm}^{-3}$, while the median of this parameter in mechanically treated wastewater was $382.1 \mathrm{mgO}{ }_{2} \cdot \mathrm{dm}^{-3}$ and it was lower than $\mathrm{BOD}_{5}$ in wastewater flowing into the plant by $21.6 \%$. The average value of COD in wastewater after mechanical treatment was $1027.3 \mathrm{mgO}_{2} \cdot \mathrm{dm}^{-3}$ and it was lower by $36.4 \%$ as compared to COD in wastewater flowing into the plant. The median of COD was $987.0 \mathrm{mgO}_{2} \cdot \mathrm{dm}^{-3}$ and this value was lower by $37.4 \%$ compared to the value of this parameter in raw wastewater. Analyzing 
Table 1. Statistical characteristics of concentration indicators of pollution in raw wastewater

\begin{tabular}{|l|c|c|c|c|c|c|}
\hline \multirow{2}{*}{ Parameters } & \multicolumn{6}{c|}{ Statistics } \\
\cline { 2 - 7 } & $\begin{array}{c}\text { Average } \\
\mathrm{mg} \cdot \mathrm{dm}^{-3}\end{array}$ & $\begin{array}{c}\text { Median } \\
\mathrm{mg} \cdot \mathrm{dm}^{-3}\end{array}$ & $\begin{array}{c}\text { Min. } \\
\mathrm{mg} \cdot \mathrm{dm}^{-3}\end{array}$ & $\begin{array}{c}\text { Max. } \\
\mathrm{mg} \cdot \mathrm{dm}^{-3}\end{array}$ & $\begin{array}{c}\text { Deviation stand. } \\
\mathrm{mg}^{-} \mathrm{dm}^{-3}\end{array}$ & $\begin{array}{c}\text { Coefficient } \\
\text { of variation }\end{array}$ \\
\hline $\mathrm{BOD}_{5}$ & 498.5 & 487.6 & 206.5 & 935.0 & 148.4 & 0.30 \\
\hline $\mathrm{COD}$ & 1615.9 & 1576.0 & 552.0 & 3074.0 & 559.7 & 0.35 \\
\hline Total Nitrogen & 106.6 & 104.2 & 44.3 & 209.3 & 31.5 & 0.30 \\
\hline Total Phosphorus & 18.2 & 17.2 & 5.4 & 51.8 & 7.9 & 0.43 \\
\hline
\end{tabular}

the concentration of biogenic parameters, it was noted that the average concentration of total nitrogen in wastewater after mechanical treatment is lower by $31.7 \%$ compared to the average concentration of this parameter in raw wastewater and it amounts to $72.9 \mathrm{mgN}_{\mathrm{og}} \cdot \mathrm{dm}^{-3}$. The median of total nitrogen is $70.1 \mathrm{mgN}_{\mathrm{og}} \cdot \mathrm{dm}^{-3}$ and it is lower in wastewater after mechanical treatment by $32.8 \%$. In the case of the second biogenic indicator, which is total phosphorus, it was found that the average concentration of this parameter is lower in mechanically treated wastewater by $35.9 \%$ compared to the concentration of this indicator in raw wastewater. The average value of total phosphorus in wastewater after mechanical treatment is $11.7 \mathrm{mgP}$ og $\mathrm{dm}^{-3}$, while the median is $10.8 \mathrm{mgP}_{\mathrm{og}} \cdot \mathrm{dm}^{-3}$. In the case of organic indicators $\left(\mathrm{BOD}_{5}\right.$ and $\left.\mathrm{COD}\right)$, it was found that the reduction rate in the mechanical part is typical and it corresponds to literature reports. However, the level of reduction for total nitrogen and total phosphorus in the mechanical part of the treatment plant is much higher than the level presented in the literature [Chmielowski and Ślizowski 2010, Młyńska et al. 2017]. Characteristic values and concentrations of the analyzed pollutant indicators in wastewater after mechanical treatment are presented in Table 2.

In the next part of this stage of the analysis, the relations between the individually tested indicators in raw wastewater and wastewater after mechanical treatment were determined. As it was stated in the works of Siwiec et al. [2018], Akratos et al. [2008] and Baczyński [2010], dependences of individual indicators in wastewater allows for forecasting the value of many indicators on the basis of the value of one of them. Due to the fact that the measurement of $\mathrm{BOD}_{5}$ is long-term and lasts up to 5 days, and this is a basic indicator showing the size of organic pollutants in the wastewater (knowing the value of COD with the measurement time lasting about 2-3 hours), it is possible to determine the size of $\mathrm{BOD}_{5}$ on this basis. If there is a close dependence of $\mathrm{BOD}_{5}$ to total nitrogen and total phosphorus, it is also possible to determine approximate concentrations of these indicators in wastewater. Such operations allow the operator to accelerate possible activities consisting in dosing an additional source of organic carbon to wastewater subjected to biological treatment processes.

Analyzing the dependence of $\mathrm{COD}$ on $\mathrm{BOD}_{5}$ in wastewater flowing into the plant and wastewater after its mechanical treatment, it was found that the correlation between these variables is (respectively) $r_{x y}=0.77$ and $r_{x y}=0.73$, and in the scale proposed by Stanisz [2006] this level of correlation is determined as very high. In both analyzed cases, the correlation is statistically significant at the level of $\alpha=0.05$. From figures $2 \mathrm{~A}$ and $2 \mathrm{~B}$, the $\mathrm{BOD}_{5}$ value can be read with the $\mathrm{COD}$ value. Additionally, from the equation $\mathrm{BOD}_{5}=169.7602+0.2034 \cdot \mathrm{COD}$, describing the regression line shown in Figure 2A (raw wastewater), it can be concluded that the change in COD value by $100 \mathrm{mgO}_{2} \cdot \mathrm{dm}^{-3}$ causes the change of the $\mathrm{BOD}_{5}$ value by $20.34 \mathrm{mgO} \cdot \mathrm{dm}^{-3}$, while from the equation $\mathrm{BOD}_{5}=144,8377=0,227 \cdot \mathrm{COD}$

Table 2. Statistical characteristics of concentration indicators of pollution in wastewater after mechanical treatment

\begin{tabular}{|c|c|c|c|c|c|c|}
\hline \multirow[b]{2}{*}{ Parameters } & \multicolumn{6}{|c|}{ Statistics } \\
\hline & $\begin{array}{l}\text { Average } \\
\mathrm{mg} \cdot \mathrm{dm}^{-3}\end{array}$ & $\begin{array}{l}\text { Median } \\
\mathrm{mg} \cdot \mathrm{dm}^{-3}\end{array}$ & $\begin{array}{c}\text { Min. } \\
\mathrm{mg} \cdot \mathrm{dm}^{-3}\end{array}$ & $\begin{array}{c}\text { Max. } \\
\mathrm{mg} \cdot \mathrm{dm}^{-3}\end{array}$ & $\begin{array}{c}\text { Deviation stand. } \\
\mathrm{mg} \cdot \mathrm{dm}^{-3}\end{array}$ & $\begin{array}{l}\text { Coefficient } \\
\text { of variation }\end{array}$ \\
\hline $\mathrm{BOD}_{5}$ & 378.0 & 382.1 & 184.3 & 649.0 & 102.8 & 0.27 \\
\hline COD & 1027.3 & 987.0 & 380.0 & 2018.2 & 332.8 & 0.32 \\
\hline Total Nitrogen & 72.9 & 70.1 & 42.5 & 125.3 & 17.1 & 0.23 \\
\hline Total Phosphorus & 11.7 & 10.8 & 5.1 & 22.8 & 3.9 & 0.34 \\
\hline
\end{tabular}



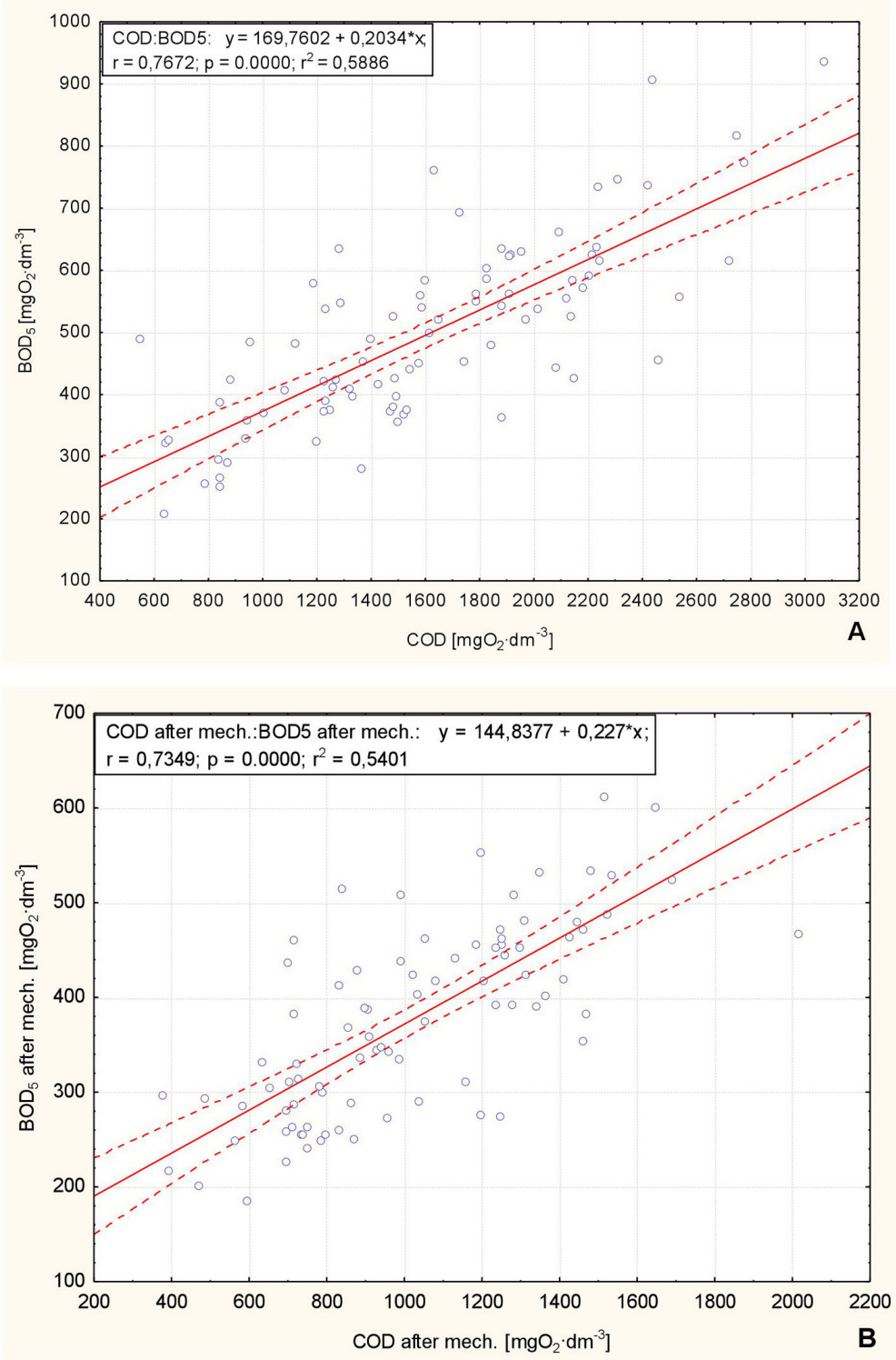

Fig. 2. Scatter plot with a regression line and a $95 \%$ confidence level for the effect of COD on $\mathrm{BOD}_{5}$ in raw wastewater (A) and after mechanical treatment wastewater (B)

describing the regression line shown in Figure 2B (wastewater after mechanical treatment), it can be concluded that the change in COD value by $100 \mathrm{mgO}_{2} \cdot \mathrm{dm}^{-3}$ causes the change of the $\mathrm{BOD}_{5}$ value by $22,7 \mathrm{mgO}_{2} \cdot \mathrm{dm}^{-3}$.

Analyzing the next dependence of total nitrogen on $\mathrm{BOD}_{5}$, it was found that the correlation between these variables in raw wastewater is $r_{x y}=0.62$ and in wastewater after mechanical treatment it is $r_{x y}=0.68$. In both cases, according to the Stanisz's scale [2006], the level of correlation is defined as high. In both analyzed cases, the correlation is statistically significant at the level of $\alpha=0.05$. The concentration of total nitrogen can be read from figures $3 \mathrm{~A}$ and $3 \mathrm{~B}$, knowing the value of $\mathrm{BOD}_{5}$. $\mathrm{TN}=41.0681+0.1315 \cdot \mathrm{BOD}_{5}$ equation, describing the regression line shown in Figure 3A (raw wastewater), indicates that a change in $\mathrm{BOD}_{5}$ by $100 \mathrm{mgO}_{2} \cdot \mathrm{dm}^{-3}$ causes a change in the concentration of total nitrogen by $13.15 \mathrm{mgTN} \cdot \mathrm{dm}^{-3}$, while $\mathrm{TN}=30.3542+0.1124 \cdot \mathrm{BOD}_{5}$ equation (describing the regression line shown in Figure 3B - wastewater after mechanical treatment) shows that a change in the $\mathrm{BOD}_{5}$ value by $100 \mathrm{mgO} \cdot \mathrm{dm}^{-3}$ causes a change in the concentration of total nitrogen by $11.24 \mathrm{mgTN} \cdot \mathrm{dm}^{-3}$.

In relation to the dependence of the second of the analyzed biogenic indicators (total phosphorus), it was found that the correlation between $\mathrm{BOD}_{5}$ and the total phosphorus in raw wastewater is $\mathrm{r}_{\mathrm{xy}}=0.51$ and it is at a high level (according to the scale). On the other hand, in 

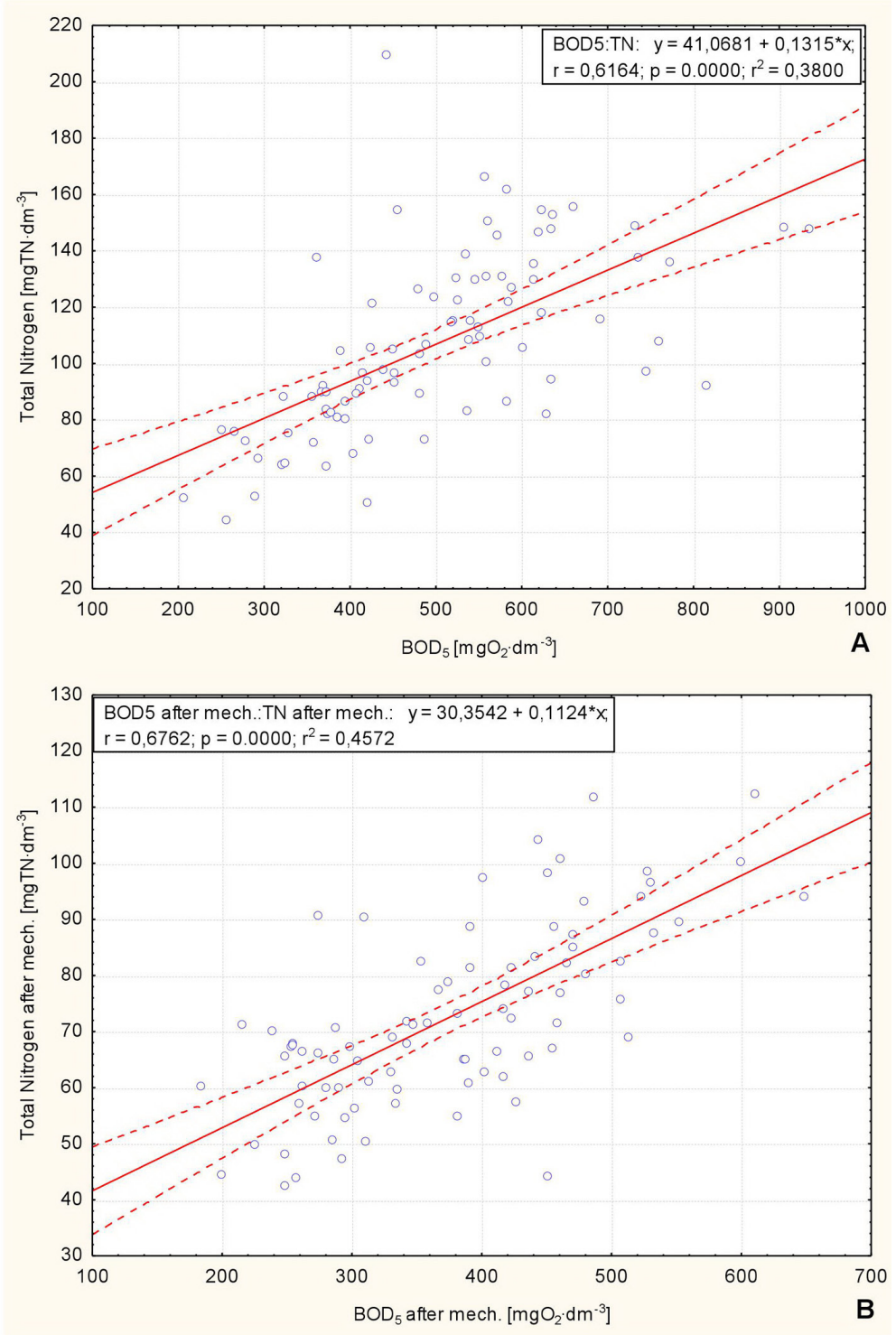

Fig. 3. Scatter plot with a regression line and a $95 \%$ confidence level for the effect of $\mathrm{BOD}_{5}$ on Total Nitrogen in raw wastewater (A) and after mechanical treatment wastewater (B)

wastewater after mechanical treatment, the correlation dependence is higher and it amounts to $r_{x y}=0.71$. This indicates a very high level of correlation. As in previous dependencies, the correlation is statistically significant at the level of $\alpha=0.05$. In reference to raw wastewater, $\mathrm{TP}=4.6286+0.0273 \cdot \mathrm{BOD}_{5}$ equation (describing the regression line shown in Figure $4 \mathrm{~A}$ ) indicates that a change in the $\mathrm{BOD}_{5}$ value by 100 $\mathrm{mgO} \cdot \mathrm{dm}^{-3}$ causes a change in the concentration of total phosphorus by $2.73 \mathrm{mgTP} \cdot \mathrm{dm}^{-3}$. In wastewater after mechanical treatment, $\mathrm{TP}=1.3799+0.0273 \cdot \mathrm{BOD} 5$ equation (describing the regression line presented in Figure 4B) indicates that a change in the $\mathrm{BOD}_{5}$ value by $100 \mathrm{mgO} \cdot \mathrm{dm}^{-3}$ causes a change in the concentration of total phosphorus by $2.73 \mathrm{mgTP} \cdot \mathrm{dm}^{-3}$.
On the basis of knowledge about the values of the analyzed indicators in individual samples of wastewater after mechanical treatment, their biodegradability was determined in a biological part of the facility. Based on the information adopted by Heidrich and Witkowski [2015], it was assumed that the processes of biological treatment are most effective if the wastewater flowing into the bioreactor is characterized by the adequate composition and interdependence, which are as follows: $\mathrm{COD} / \mathrm{BOD}_{5} \leq 2 ; \mathrm{BOD}_{5} / \mathrm{TN} \geq 4$; $\mathrm{BOD}_{5} / \mathrm{TP} \geq 25$. In order to illustrate (in detail) in how many wastewater samples these dependencies were met, the histograms of the frequency of occurrence of particular relations have been prepared. In each case of the analyzed 3 dependencies, 4 class ranges were proposed with the 

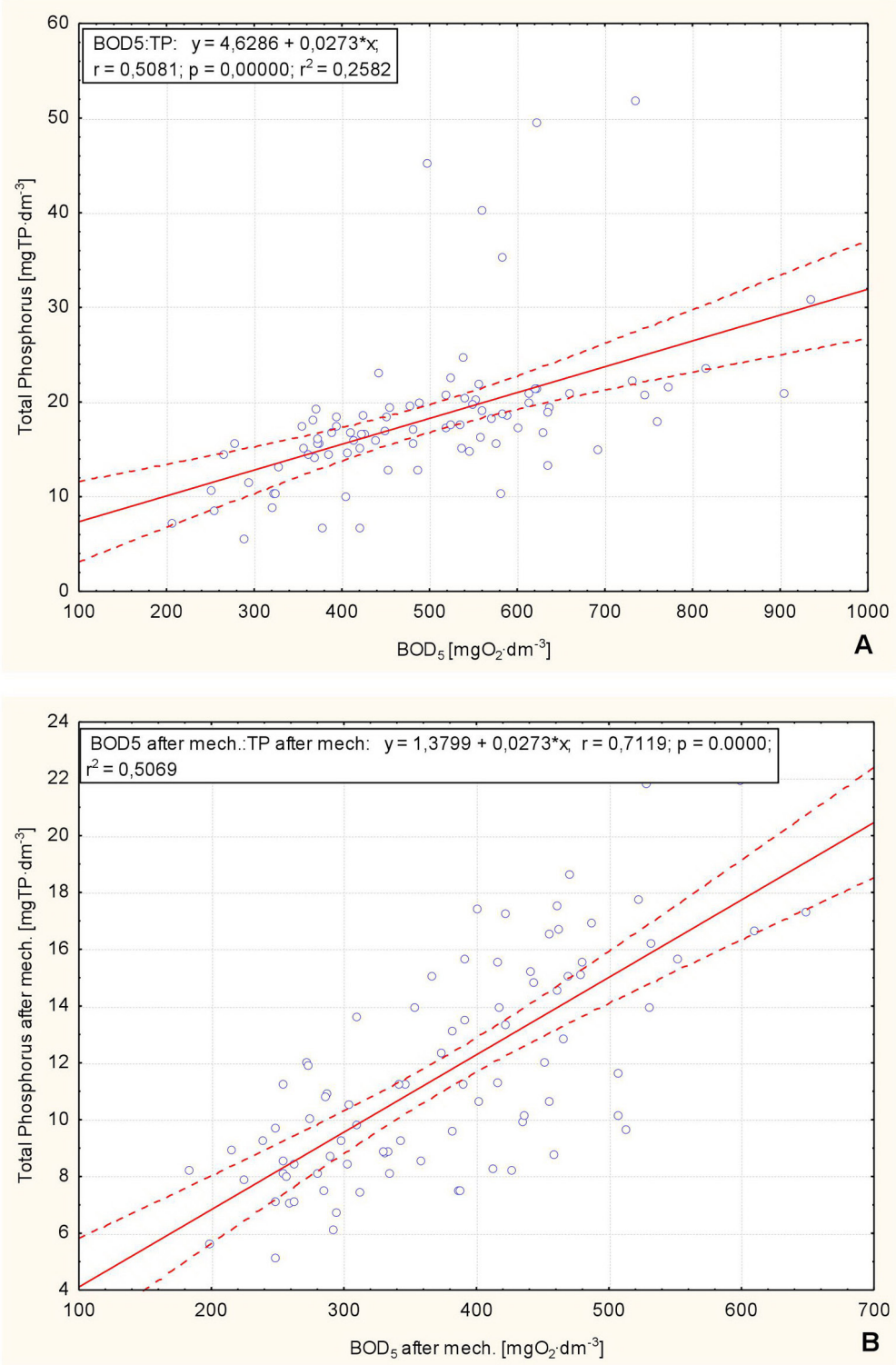

Fig. 4. Scatter plot with a regression line and a $95 \%$ confidence level for the effect of $\mathrm{BOD}_{5}$ on Total Phosphorus in raw wastewater (A) and after mechanical treatment wastewater (B)

following intervals: every 1 for the $\mathrm{COD} / \mathrm{BOD}_{5}$ ratio, every 2 for the $\mathrm{BOD}_{5} / \mathrm{TN}$ ratio and every 12.5 for the $\mathrm{BOD}_{5} / \mathrm{TN}$ ratio. The histograms in Figures $5 \mathrm{~A}, 5 \mathrm{~B}$ and $5 \mathrm{C}$ present the characteristic percentages of the analyzed dependencies. For each dependence, an advantageous dependence was marked in orange, whereas an unfavorable dependence was marked in blue. Analyzing the dependence of $\mathrm{COD} / \mathrm{BOD}_{5}$ in wastewater after mechanical treatment (Figure 5A), it was found that only $11.5 \%$ of the analyzed cases were below 2, i.e. they fulfilled the condition of biodegradability of easily decomposable organic compounds. In the case of the dependence of the amount of organic compounds expressed as $\mathrm{BOD}_{5}$ to the concentration of biogenic compounds expressed as total nitrogen and total phosphorus (Figure 5B and $5 \mathrm{C}$ ), it was found that in approx. $12 \%$ of cases, wastewater is not susceptible to nitrification, denitrification and dephosphatation processes.

\section{CONCLUSIONS}

Based on the conducted analysis, it was found that the values of the analyzed indicators in wastewater flowing into the treatment plant were typical for household wastewater. The degree of reduction for organic pollutants expressed as COD and $\mathrm{BOD}_{5}$ in the mechanical part of the facility was on an average level of $24.2 \%$ and $36.4 \%$. The reduction rate of biogenic indicators expressed as total 


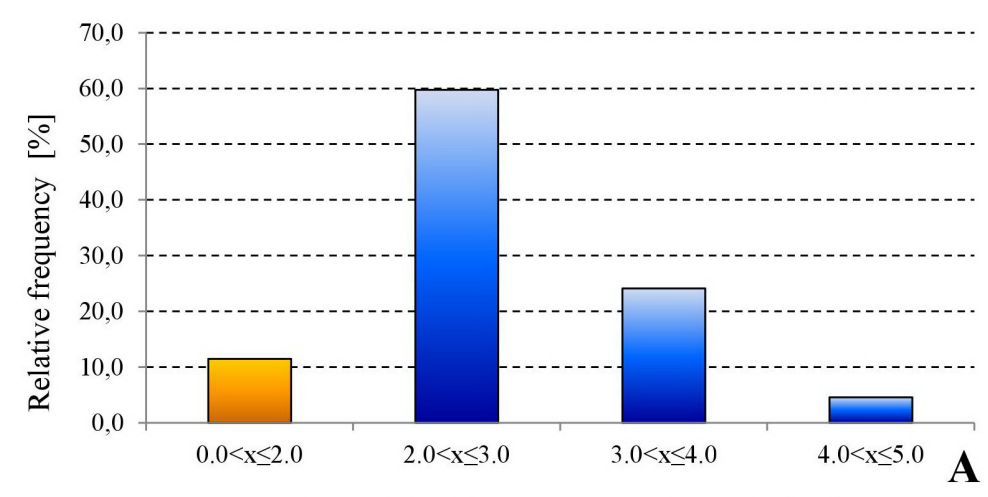

Ratio $\mathrm{COD} / \mathrm{BOD}_{5}$ in wastewater after machanical treatment

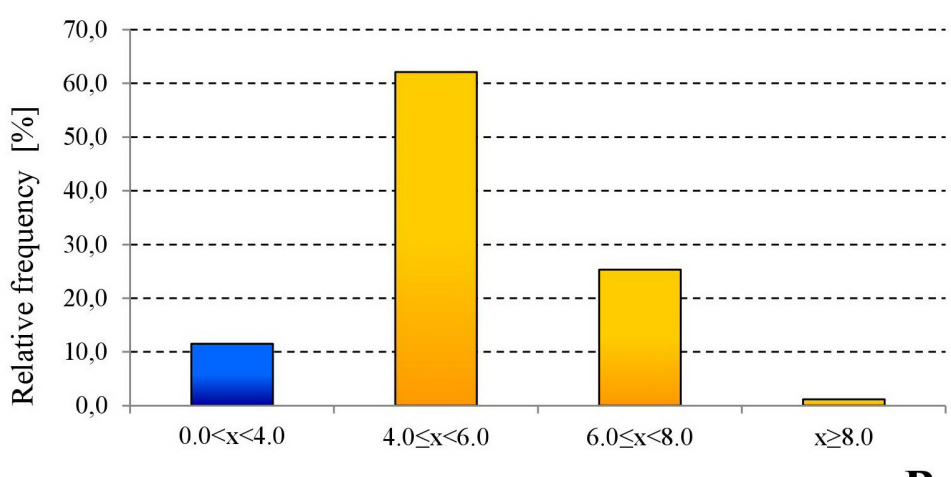

Ratio $\mathrm{BOD}_{5} / \mathrm{TN}$ in wastewater after machanical treatment

B

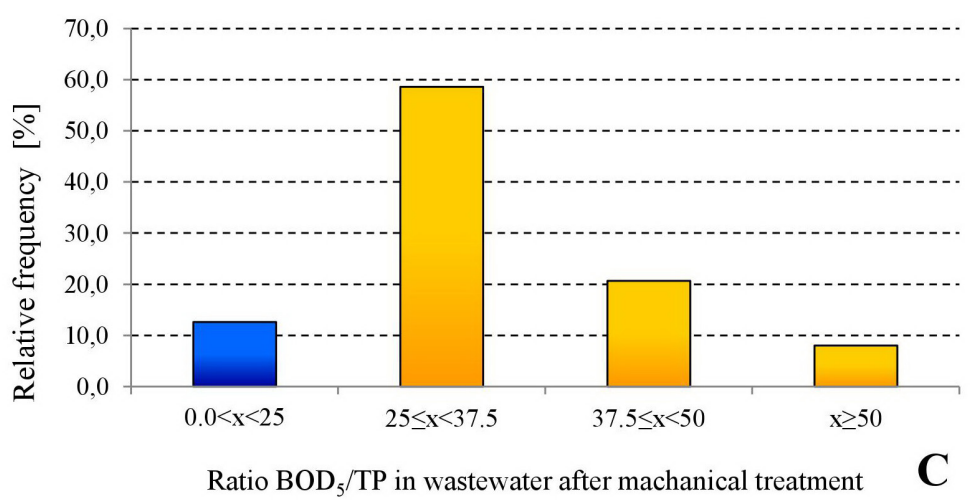

Fig. 5. The histogram of the frequency of dependence $\mathrm{COD} / \mathrm{BOD}_{5}(\mathrm{~A}), \mathrm{BOD}_{5} /$ $\mathrm{TN}(\mathrm{B})$ and $\mathrm{BOD}_{5} / \mathrm{TP}(\mathrm{C})$ in wastewater after mechanical treatment.

nitrogen and total phosphorus was on an average level of $31.7 \%$ and $35.9 \%$ (respectively). In case of susceptibility to biological degradation processes of organic pollutants, wastewater after mechanical treatment has an unfavorable $\mathrm{COD} / \mathrm{BOD}_{5}$ ratio. This indicates the need for periodic dosing of an additional source of organic carbon for wastewater before its biological treatment in the period when this ratio is unfavorable. Regarding the susceptibility of wastewater to nitrification, denitrification and dephosphatation processes, in the majority of cases, wastewater is susceptible to processes and additional dosing of organic compounds will have a positive effect on these processes.

\section{REFERENCES}

1. Akratos C.S., Papaspyros J.N.E., Tsihrintzis V.A. 2008: An artificial neural network model and design equations for BOD and COD removal prediction in horizontal subsurface flow constructed wetlands. Chemical Engineering Journal, 143, 96-110.

2. Arnold E., Bohm B., Wilderem P. A. 2000. Application of activated sludge and biofilm sequencing bath reactor technology to treat reject water from sludge dewatering systems: a comparison. Water Science and Technology, 41, 115-122.

3. Barnard J. L. 2000. Projektowanie oczyszczalni z osadem czynnym usuwających związki biogenne. 
Materiały seminarium szkoleniowego „Filozofia projektowania a eksploatacja oczyszczalni ścieków" LEM PROJEKT s.c. Kraków, 13-60.

4. Bergel T., Kaczor G., Kudlik K. 2017. Analiza przyczyn nieuzasadnionego wzrostu natężenia przepływu ścieków w gminnej sieci kanalizacji sanitarnej. Gaz, Woda i Technika Sanitarna, 4, 182-185.

5. Baczyński T. 2010. Przegląd metod służących wyznaczaniu frakcji ChZT w ściekach. Gaz, Woda i Technika Sanitarna, 10, 29-35 (in Polish).

6. Bugajski P., Pawełek J., Kurek K. 2017a. Concentrations of organic and biogenic pollutants in domestic wastewater after mechanical treatment in the aspect of biological reactor design. Infrastructure and Ecology of Rural Areas, IV/3-2017, 1811-1822.

7. Bugajski P., Nowobilska-Majewska, E., Kurek K. $2017 \mathrm{~b}$. The variability of pollution load of organic, biogenic and chromium ions in wastewater inflow to the treatment plant in Nowy Targ. Journal of Water and Land Development, 35(X-XII), 11-17.

8. Bugajski P., Bergel T. 2008. Wielkości wybranych stężeń zanieczyszczeń w ściekach bytowych odpływających z terenów wiejskich. Gaz, Woda i Technika Sanitarna, 9, 28-29.

9. Chmielowski K., Ślizowski R. 2010. Ocena skuteczności oczyszczania ścieków w oczyszczalni ścieków w Nowym Sączu-Wielopolu. Infrastruktura i Ekologia Terenów Wiejskich, 2, 155-167.

10. Dymaczewski Z. i in. (2011). Poradnik Eksploatatora Oczyszczalni Ścieków. PZITS o/Wielkopolski, Poznań.

11. Dz.U./2014/1800 Regulation of the Minister of the Environment of 18 November 2014 on conditions to be met when introducing sewage into waters or into the ground, and on substances particularly harmful to the aquatic environment (in Polish).

12. EN 1899-1 and EN 1899-2 and for self-checks.

13. Heidrich Z., Witkowski A. 2015. Urządzenia do oczyszczania ścieków: projektowanie, przykłady obliczeń. Wydawnictwo Seidel-Przywecki, Warszawa.

14. Heidrich Z., Kozak T. 2009. Jednostkowe ładunki zanieczyszczeń charakteryzujące ścieki miejskie. Gaz, Woda i Technika Sanitarna, 12, 20 - 22.

15. Heidrich Z. Przydomowe oczyszczalnie ścieków - poradnik. Centralny Ośrodek Informacji
Budownictwa, Warszawa1998.

16. Kaczor G. 2009. Stężenia zanieczyszczeń w ściekach odprowadzanych $\mathrm{z}$ wiejskich systemów kanalizacyjnych województwa małopolskiego. Infrastruktura i Ekologia Terenów Wiejskich 9, 97-104.

17. Klaczyński E. 2016. Komunalne oczyszczalnie ścieków - podstawy projektowania i eksploatacji. Wyd. Envirotech sp. z o.o. ISBN 978-83-901701-5-2.

18. Klimiuk E., Łebkowska M. Biotechnologia w ochronie środowiska. Wydawnictwo naukowe PWN, Warszawa 2008.

19. Łomotowski J., Szpindor A. 1999. Nowoczesne systemy oczyszczania ścieków. Wydawnictwo Arkady, Warszawa.

20. Młyńska A., Chmielowski K., Młyński D. 2017. Analiza zmian jakości ścieków w trakcie procesów oczyszczania na oczyszczalni w Przemyślu. Inżynieria Ekologiczna, 18, 18-26.

21. PN-ISO 6060:2006 - Water quality - Determination of chemical oxygen demand.

22. PN-EN 25663:2001 - Water quality - Determination of Kjeldahl nitrogen - Method after mineralization with selenium.

23. Pawełek, J. (2016). Degree of Development and Functionality of the Water Supply and Sewage Systems in Rural Poland. Barometr Regionalny, 14(1), 141-149.

24. Siwiec T., Reczek L., Michel M., Gut B., Hawer-Strojek P., Czajkowska J., Jóźwiakowski K., Gajewska M., Bugajski P. 2018. Correlations between organic pollution indicators in municipal wastewater. Archives of Environmental Protection, 44 (4), 50-57.

25. Stanisz, A. 2006. An affordable statistic course with the use of STATISTICA PL on the examples of Tom 1 medicine. Basic statistics. Statystyki podstawowe. Wydawnictwo StatSoft Polska Sp. z o.o. Kraków, 532. (in Polish)

26. Stańko G., Sytek-Szmeichel K., Heidrich Z. 2016. Dane wejściowe do projektowania miejskich oczyszczalni ścieków (wg. stanu na koniec 1015 r.). Gaz, Woda i Technika Sanitarna, 7, 272-276.

27. Wawrzynek, J. Methods of descriptiaon and statistical inference. Wydawnictwo Akademii Ekonomicznej im. Oskara Langego we Wrocławiu, 2007, 37, Wrocław. 